DOI: https://doi.org/10.32353/khrife.1.2021.04

УДК 343.98

\title{
О. О. Юхно,
}

доктор юридичних наук, професор, завідувач кафедри кримінального процесу та організації досудового слідства Харківського національного університету внутрішніх справ, м. Харків, Україна,

ORCID: https://orcid.org/0000-0002-4771-0531, e-mail: u-kafedra@ukr.net

\section{Криміналістичне забезпечення Аіяльності Установ суАових експертиз та органів АосуАового розсліАування і Аізнання У протиАії злочинності}

Розглянуто проблемні питання криміналістичного забезпечення діяльності установ судових експертиз та органів досудового розслідування $i$ дізнання у протидіі кримінальним правопорушенням. Проаналізовано національне кримінально-прочесуальне законодавство, відомчу нормативно-правову базу, генезис наукових позицій щчодо теоретичних і прикладних питань криміналістичного забезпечення у цььому напрямі, а також щзодо поняття та сутності криміналістики як науки, досліджено питання сучасного стану ї̈ розвитку, наявні проблемні питання та визначено иляхи вдосконалення. За результатами дослідження надано конкретні пропозиичї й рекомендації щуодо вивченого напряму діяльності.

Ключові слова: криміналістика, генезис, наукова позиція, удосконалення, слідчий, дізнавач, прокурор, установи судових експертиз, судовий експерт, забезпечення, протидія злочинності, наука, форми, методи, методика, науково-технічні засоби.

Постановка наукової проблеми. Станом на сьогодні протидія злочинності є одним із головних чинників забезпечення стабільного політичного, економічного та соціального розвитку України, що знаходить своє закріплення в окремих галузях права, у законодавчій і правозастосовній практиці. Криміналістика завжди виконувала значну кількість функцій у діяльності органів досудового розслідування та дізнання (зокрема, у питаннях протидії злочинності). Започаткування криміналістики пов'язано з потребами країни й науки в розробленні нових форм, методів і засобів викриття, розкриття та розслідування злочинів. Водночас сучасний стан розвитку суспільства, реформування законодавства, правоохоронних, зокрема слідчих органів і органів дізнання, експертних установ і судових інстанцій, значні зміни в криміногенній обстановці країни, поява нових видів злочинів і механізмів їх вчинення із застосуванням сучасних досягнень науки й техніки, зокрема комп'ютерних та телекомунікаційних технологій, та наявні проблеми у правозастосуванні вимагають подальшої, але доволі кардинальної зміни й розвитку криміналістики та її наукової парадигми (із використанням при цьому інновацій і визначенням шляхів їх удосконалення). У зв’язку 
iз зазначеним, теоретичні та прикладні проблемні питання криміналістики підлягають ретельному дослідженню. При цьому слід звернути увагу на наявність таких проблемних питань, як удосконалення криміналістичної характеристики окремих видів злочинів, криміналістичної методики, що поєднує криміналістичну техніку та тактику, питань подальшого поширення й застосування у правозастосовній і експертній діяльності перспективних для досудового розслідування молекулярно-генетичних експертиз, зокрема методів ДНК-аналізу, та ін.

Аналіз основних досліджень і публікацій. Проблемні питання криміналістики та порушеної теми досліджували Р. С. Бєлкін, В. П. Бахін, В. Д. Берназ, А. І. Вінберг, І. Ф. Герасимов, В. І. Гончаренко, І. Ю. Горбатенко, М. М. Дидик, В. А. Журавель, Г. А. Матусовський, Е. І. Мостовщиков, Н. С. Карпов, В. В. Кікінчук, В. О. Коновалова, С. І. Перлін, Р. Л. Степанюк, М. С. Строгович, В. Д. Пчолкін, В. В. Тищенко, В. Ю. Шепітько, О. О. Ейсман, М. П. Яблоков, І. М. Якимов та ін. ${ }^{1}$ Однак, більшість цих науковців вивчали цю проблематику з точки зору аналізу окремих тенденцій розвитку криміналістичної науки. Їхні наукові праці привернули увагу до окремих тенденцій розвитку криміналістичної науки та їі завдань, ролі в системі наукового знання, проте, здебільшого не мали концептуального й системного характеру, а комплексно проблему місця криміналістики у системі юридичних наук і криміналістичне забезпечення органів досудового слідства та дізнання (зокрема, у протидії злочинності) не досліджували. У 1970-ті рр. Г. А. Матусовський на рівні докторської дисертації сформулював принципово важливі положення криміналістичної науки, які тривалий час були загальновизнаними, проте, у подальшому, незважаючи на зміни у державотворенні, розширення спектру наукових уявлень тощо, їх не було переглянуто. Пізніше, на базі кореляції призначення правових наук, С. В. Смахтін ${ }^{2}$ на монографічному рівні дослідив взаємозв'язок криміналістики

${ }^{1}$ Белкин Р. С. Курс криминалистики : в 3-х т. Т. 1 : Общая теория криминалистики. Москва, 1997 ; Бахин В. П. Следственная ситуация и тактическое решение // Специализированный курс криминалистики : учебник. Киев, 1987 ; Берназ В. Д., Бірюков В. В., Волобуєв А. Ф. Криміналістика : підручник ; за заг. ред. А. Ф. Волобуєва. Харків, 2011 ; Матусовский Г. А. Криминалистика в системе научных знаний. Харьков, 1976 ; Шепітько В. Ю. Тенденції і перспективи розвитку криміналістики (концептуальність підходів і дискусійність поглядів). Актуальні проблеми криміналістики : мат-ли Міжнар. наук.-практ. конф. (Харків, 25-26.09.2003). Харків, 2003 ; Журавель В. А. Ситуація слідча // Велика українська юридична енциклопедія : у 20 т. Т. 20 : Криміналістика, судова експертиза, юридична психологія ; редкол. В. Ю. Шепітько (голова) та ін. Харків, 2018. С. 743-744 ; Шепітько В. Ю., Журавель В. А., Коновалова В. О. Криміналістика : підручник : у 2 т. Т. 1 ; за ред. В. Ю. Шепітька. Харків, 2019 ; Шепітько В. Ю., Журавель В. А. Типові системи тактичних прийомів: проблеми розробки та ефективного застосування. Питання боротьби зі злочинністю : зб. наук. пр. Харків, 2009. Вип. 17. С. 237-251 та ін.

${ }^{2}$ Смахтин Е. В. Криминалистика: соотношение с уголовным и уголовно-процессуальным правом : монография. ; под общ. ред. А. С. Подшибякина. Москва, 2009. 232 с. 
3 кримінальним правом і кримінальним процесом, хоча й залишив поза увагою питання інтеграції всіх галузей єдиної системи кримінально-правових наук і місця серед них криміналістики. Доволі потужною спробою вирішити окремі питання криміналістики в національній системі юридичних наук стала докторська дисертація М. В. Даньшина «Місце криміналістики у системі юридичних наук» (2014), у якій автор, спираючись на динамічну трансформацію наукових знань, розглянув питання визначення місця і зв'язків криміналістики на підставі кардинальних змін у КПК України, появи нових юридичних наук, а також різних теоретичних конструкцій («судової експертології», «криміналістичної адвокатології», «криміналістичної ейдології», «криміналістичної феноменології» та ін.), які відображають певні тенденції розвитку науки криміналістики або ідеї науковців (як окремих дослідників, так і їхніх груп). У своїй роботі він слушно поставив таке проблемне питання: «Кому адресовано наукові положення криміналістики та ї̈ рекомендації $і$ хто є користувачем ї̈ знань» та наголосив, що ця обставина є детермінантною і зумовлює зміни в криміналістиці, інтегрує іiі з іншими науками та визначає шляхи їі розвитку ${ }^{1}$. Зазначене ним та іншими науковцями спонукало до обрання теми цієї статті.

Мета статті: аналіз національного кримінального процесуального законодавства, відомчих нормативно-правових актів, що регламентують криміналістичне забезпечення органів досудового розслідування і дізнання у протидії злочинності, наявність проблемних теоретичних та прикладних питань сучасного стану розвитку криміналістики.

Основними завданнями є напрацювання відповідних пропозицій і рекомендацій щодо шляхів вирішення виявлених проблемних питань на теоретичному й законодавчому рівні та у правозастосовній діяльності.

Наукова новизна дослідження. Наукове дослідження має такі елементи новизни: уперше його здійснено на стику криміналістики та кримінального процесу зі встановленням наявних проблемних питань стану розвитку науки криміналістики у сучасному періоді; удосконалено напрацювання пропозицій і рекомендацій щодо розв'язання виявлених проблем розвитку шляхом кардинальних змін наукової парадигми криміналістики із застосуванням інновацій.

Викладення основного матеріалу дослідження. Протидії злочинності поступилося місцем більш стале поняття «боротьба зі злочинністю», яким радянська влада послуговувалася як ідеологічним постулатом кінцевої мети в перемозі над злочинністю. Історія та правозастосовна діяльність усієї правоохоронної системи визначили абсурдність цієї політичної платформи. На нашу думку, протидія злочинності складається із системи та комплексного впливу на злочинність та окремі їі чинники. 3 нами погоджуються й інші науковці. Так, А. В. Майоров зазначає, що наявні способи

${ }^{1}$ Даньшин М. В. Місце криміналістики у системі юридичних наук : автореф. дис. ... Д-ра юрид. наук. Харків, 2014. 40 с. 
реагування на злочинність можна представити у вигляді певної системи, а саме системи протидії злочинності, яка містить заходи профілактичного й попереджувального впливу як на окремі види злочинів, так і на злочинність загалом. Така система має містити засоби, способи і прийоми, які застосовують не тільки правоохоронні органи, а й органи місцевого самоврядування, громадські та інші організації, а також самі громадяни. При цьому механізм реалізації протидії злочинності вимагає серйозних зусиль не тільки з боку держави, а й суспільства та окремих індивідів. Очікуваний результат протидії злочинності може бути досягнуто тільки на основі використання широкого комплексу загально-соціальних і спеціальних заходів попередження ${ }^{1}$, що ми підтримуємо, і це підтверджує актуальність обраної теми нашого дослідження.

Дослідженнями встановлено, що криміналістика виконувала значну кількість функцій у діяльності органів досудового розслідування та дізнання (зокрема, у питаннях протидії злочинності). Зародження криміналістики пов'язано з потребами країни та науки в розробленні нових форм, методів та засобів викриття, розкриття і розслідування злочинів. За визначенням Р. С. Бєлкіна, формування криміналістики як науки вчені датують кінцем XIX ст. ${ }^{2}$, що ми підтримуємо. При цьому історично вона формувалась із надр кримінальної процесуальної науки, у зв'язку із чим тісно пов'язана 3 теорією доказів. Інші науковці зазначали, що криміналістика є наукою про судові докази - наукою доказового права та діалектикою кримінального процесу, це процедура в динаміці, у розвитку; вона передбачає використання творчого підходу, ситуаційної зумовленості, наявності альтернативи в обранні певних шляхів, методів, прийомів, методик. За визначенням сучасних дослідників, криміналістика є самостійною галуззю наукового знання, яка привертає до себе увагу передусім тим, що допомагає встановити істину, проникнути в невідоме. Її формування та становлення супроводжувалися гострими дискусіями й суперечками. У сучасному стані існують різні наукові позиції щодо предмета криміналістики, зокрема: 1) наука про розслідування злочинів; 2) наука про сукупність технічних засобів, тактичних прийомів і методичних рекомендацій. Однак, щодо першої наукової позиції слід зазначити, що вона застаріла, оскільки сьогодні розслідують не тільки злочини, а й кримінальні проступки. Водночас усі зазначені вище наукові позиції звужують реальний предмет криміналістики й закономірності, які вона вивчає, але підкреслюють їі забезпечувальний характер у протидії злочинності. Наприклад, Р. С. Бєлкін зазначав, що (як процесуальна, так і непроцесуальна) діяльність правоохоронних органів вирішує усі подібні види завдань на базі своїх теоретичних засад, використовуючи для цього весь

${ }^{1}$ Майоров А. В. Виктимологическая модель противодействия преступности : монография. Москва, 2014. С. 57.

2 Белкин Р. С. Криминалистическая энциклопедия. 2-е изд., доп. Москва, 2000. C. 5. 
властивий їм арсенал засобів і методів, а за можливості - застосовуючи сили й методи суміжних галузей діяльності. Окрім цього, слід зазначити, що особливо гостро точилася дискусія щодо предмета криміналістики у 1950-ті та в 1970-ті рр. Це було пов'язано зі складністю об'єкта пізнання: зокрема, із вивченням самої злочинної діяльності й діяльності щодо протидії злочинності. У ході дискусії 1967-1968 рр. Р. С. Бєлкін намагався сформулювати визначення предмета криміналістики, яке на той час набуло поширення: зокрема, що ним є «наука про закономірності виникнення, збирання, дослідження, оцінки та використання доказів $і$ засновані на пізнанні циих закономірностей засоби і методи судового дослідження та попередження злочинів» ${ }^{1}$. Це поняття враховувало основний зміст предмета криміналістики. Станом на сьогодні у криміналістиці розглядають двоєдиний об'єкт пізнання, зокрема: злочинну діяльність (злочинну поведінку), діяльність з виявлення, розкриття, досудового розслідування слідчим і дізнавачем та встановлення істини у кримінальному провадженні. Найбільш слушним визначенням, на нашу думку, слід вважати наукову позицію В. Ю. Шепітька, який зазначає, що криміналістика — це наука про закономірності злочинної діяльності та іiі відображення в джерелах інформації, що слугують основою для розроблення засобів, прийомів і методів збирання, дослідження, оцінки та використання доказів з метою розкриття, розслідування, судового розгляду та попередження злочинів ${ }^{2}$. Така дефініція підкреслює прагматичний характер криміналістики, спрямованість іiі на створення наукових концепцій для практики протидії злочинам і кримінальним проступкам (кримінальним правопорушенням). Зі свого боку, В. І. Гончаренко зазначав, що у прикладному аспекті розвиток криміналістики завжди характеризувався постійним залученням, удосконаленням або пристосуванням для своїх потреб досягнень природничих і технічних наук ${ }^{3}$, що ми підтримуємо.

Теоретичні напрями криміналістики потребують переосмислення з урахуванням реформування правоохоронних органів, експертних установ, прокуратури й судових інстанцій, удосконалення правозастосовної діяльності та кримінального, кримінального процесуального й іншого законодавства, а також нормативно-правових актів, зокрема відомчих і міжвідомчих, появи нових учасників кримінального провадження - дізнавача, керівника органу дізнання тощо й напрацювання іiі нових концепцій. У сучасному стані розвиток криміналістики характеризується формуванням загальної та окремих теорій, розробленням і запровадженням сучасних науково-технічних розробок, засобів зв'язку, телекомунікаційних та інформаційних

${ }^{1}$ Его же. Общая теория советской криминалистики. Саратов, 1986. С. 20.

${ }^{2}$ Криміналістика : підручник ; за ред. В. Ю. Шепітька. 3-тє вид., перероб. і допов. Київ, 2004. С. 7-8.

${ }^{3}$ Гончаренко В. И. Использование данных естественных и технических наук в уголовном производстве (Методологические вопросы) : монография. Киев, 1980. C. $75-76$. 
мереж і технологій у практику протидії злочинам та кримінальним проступкам, що пов'язано з удосконаленням прийомів криміналістичної тактики й розробленням сучасних методик розслідування нових видів кримінальних правопорушень. Накопичення нових наукових знань на певних історичних етапах призводить до зміни наукової парадигми криміналістики, зокрема - зміни систем панівних ідей. Криміналістика - це наука, яка вдосконалюється в динаміці, змінюються їі межі, сфери впливу, запроваджуються нові напрями та пропонуються нові теорії. Одним із важливих напрямів криміналістичного забезпечення діяльності органів досудового розслідування й дізнання у протидії кримінальним правопорушенням $\epsilon$ запровадження сучасних інновацій. Їх запровадження у діяльність слідчого, дізнавача, прокурора, детектива, працівника оперативного підрозділу Національної поліції, працівників Служби безпеки України, НАБУ, Державного бюро розслідувань та інших органів зумовлене обов'язками щодо вирішення значної кількості задач у розумні, але обмежені строки; браком технічних засобів, як перебувають сьогодні на озброєнні відповідних правоохоронних органів; наявними проблемами у координації та взаємодії 3 відповідними спеціалістами, фахівцями різних галузей знань та оперативними працівниками; браком і дефіцитом інформації про розслідувану подію, що відбулася в минулому; обмеженістю надійних джерел здобуття відповідної інформації; протидією досудовому розслідуванню з боку зацікавлених осіб. Запровадження інновацій сприяє підвищенню ефективності досудового розслідування й дізнання та унеможливлює помилки або зменшує їхню кількість у такій діяльності. Їх запровадження в діяльність слідчих, дізнавачів, прокурорів можливе в таких заходах: а) розроблення та запровадження у практичну діяльність новітніх науково-технічних засобів з метою виявлення, збирання, фіксування й оцінювання і попереднього дослідження доказів; б) опрацювання пропозицій щодо впровадження нових телекомунікаційних та інших інформаційних технологій у діяльність слідчого, дізнавача, прокурора; в) розроблення нових прийомів, методів, методик проведення окремих слідчих (розшукових) дій і досудового розслідування та дізнання загалом. Криміналістична техніка є розділом криміналістики, який виник завдяки запровадженню досягнень природничих і технічних наук для виявлення слідів кримінальних правопорушень та здобуття іншої криміналістично необхідної інформації.

Розширення й оновлення переліку науково-технічних засобів, які застосовують у протидії кримінальним правопорушенням (за умови дотримання кримінального процесуального механізму), порушує питання про доцільність перевірки їх науковості, заборону використання антинаукових прийомів та тих, що не відповідають принципу демократичності й доктринальності кримінального судочинства. Для того щоб науково-технічні засоби під час виявлення, розкриття та розслідування кримінальних правопорушень сприяли підвищенню якості й ефективності досудового розслідування, 
пропонується більш широко застосовувати допомогу спеціалістів. Невипадково в чинному КПК України 2012 р. введено новели, які уточнювали й доповнювали 2020 р., зокрема: ст. 71 «Спеціаліст» і ст. 72 «Відповідальність спеціаліста» ${ }^{1}$. Крім цього, у підрозділах районних відділів поліції та при слідчих управліннях ГУНП в областях, згідно з наказом Національної поліції України від 24.12.2020 р. «Про організаційно-штатні зміни» посади інспекторів-криміналістів (уведені 2017 р.) перейменовано у посади спеціалістів-криміналістів, завдання яких — надавати допомогу слідчим поліції під час проведення оглядів місць подій учинених кримінальних правопорушень і під час проведення окремих слідчих (розшукових) дій та ін. Водночас простежується тенденція щодо протиставлення спеціаліста і слідчого, дізнавача; відмежування слідчого, дізнавача від застосування науково-технічних засобів; виконання спеціалістом діяльності на свій розсуд, а не надання допомоги слідчому. У сучасних умовах появи нових видів кримінальних правопорушень, більшої технічної й іншої оснащеності осіб, які їх вчиняють, діяльність слідчого, дізнавача, прокурора, судді потребує негайного технічного переоснащення. Останніми роками вжито певних заходів із запровадження в діяльність органів досудового розслідування та дізнання комбінованих комплектів слідчого, зокрема: уніфікований комплект слідчого; комплекти вузької спрямованості; комплект пошукових засобів слідчого (набір-пошук); комплект науково-технічних засобів для огляду місця пожежі (набір-пожежа); комплект науково-технічних засобів для огляду вибухових пристроїв і місця вибуху (набір-вибух); комплект науково-технічних засобів для роботи з мікрооб'єктами (набір-мікро, або «Молекула»); комплект для роботи зі слідами рук (дактилоскопічний набір); набір слідчого для огляду документів та ін.

Станом на сьогодні одним із найбільш важливих досягнень ХХ століття в цій сфері є розроблення та впровадження методів ДНК-аналізу в діяльність правоохоронних органів, установ судової експертизи й судових інстанцій 3 метою збирання, дослідження, оцінювання та використання орієнтовної й доказової інформації у кримінальному судочинстві. До сьогодні в національній криміналістиці не приділяли належної уваги питанням криміналістичного дослідження ДНК (молекулярно-генетичним дослідженням), що $є$ наслідком відсутності навчально-методичної літератури із цього напряму. Також не визначено єдиного підходу до місця молекулярно-генетичного аналізу в судовій експертизі; паралельно розвиваються криміналістичний і судово-медичний аспекти цієї проблематики. Першу в колишньому СРСР генно-ідентифіковану експертизу провів 1988 р. експерт П. Іванов у справі розумово відсталого бродяжки Сопова, якого було викрито у згвалтуванні

${ }^{1}$ Кримінальний процесуальний кодекс України : Закон України від 13.04.2012 p. № 4651-VI (зі змін. та допов.). URL: https://zakon.rada.gov.ua/laws/show/4651-17 (дата звернення: 18.09.2020). 
й убивстві двох літніх жінок ${ }^{1}$. В Україні молекулярно-генетичні експертизи проводять 31992 р., зокрема, із застосуванням радіаційної позначки таку експертизу провів експерт Державного науково-дослідного експертно-криміналістичного центру МВС України Н. М. Дяченко у справі про вбивство ${ }^{2}$. Того самого року такі експертизи почали проводити в Одеському обласному бюро судово-медичної експертизи ${ }^{3}$. Досліджуючи стан їх використання сьогодні, Р. Л. Степанюк, С. І. Перлін, В. В. Кікінчук ${ }^{4}$ зазначили, що застосування технологій криміналістичного дослідження ДНК під час розслідування кримінальних правопорушень є потужним інструментом протидії злочинності, а молекулярно-генетичні дослідження від року до року відіграють усе більшу роль (зокрема, у протидії тяжким злочинам та ін.). В умовах військових дій на Сході України та збільшення терористичних загроз вагоме значення має застосування можливостей таких досліджень 3 метою встановлення особистості невпізнаних трупів і їхніх частин, обгорілих трупів та ін. Окрім цього, методи ДНКаналізу ефективно використовують у цивільному судочинстві для вирішення справ про встановлення батьківства, визначення біологічної спорідненості людей, а також у разі виявлення бездомних дітей і неповнолітніх або осіб, які втратили пам'ять, та ін. Отже, судова молекулярна генетика, по суті, є міждисциплінарною сферою наукових знань, досягнення якої активно використовують у криміналістиці й судовій медицині. Її криміналістичне значення $є$ особливо важливим, тому що ідентифікація особи за іiі генетичними ознаками належить до найбільш точних методів ототожнення людини. Зі свого боку, генотипоскопія як розділ криміналістичної техніки має посісти гідне місце у структурі криміналістичної науки, а відповідні іiі положення - стати частиною фахової підготовки юристів, зокрема майбутніх слідчих, прокурорів, адвокатів і суддів ${ }^{5}$, що ми підтримуємо.

Станом на сьогодні доволі актуальним напрямом удосконалення діяльності слідчого, дізнавача, прокурора $є$ iї комп'ютерізація, тому що в сучасному світі неможливо ефективно працювати без створення інтегрованих баз даних, банків знань, інформаційних систем, які мають змогу багатократно спростити пошук, аналіз, передавання й оброблення інформації. Правоохоронні органи й експертні установи використовують у практичній діяль-

${ }^{1}$ Мостовщиков Е. Профессор на тропе войны. Русский репортер. 10.04.2014. URL: https://expert.ru/russian_reporter/2014/14/professor-na-trope-vojnyi (дата звернення: 20.02.2021).

2 Дяченко Н. М. Основні етапи розвитку молекулярно-генетичної експертизи в Державному науково-дослідному експертно-криміналістичному центрі МВС України. Криміналістичний вісник. 2011. № 1 (15). С. 166-167.

${ }^{3}$ Дунаєв О. В. Актуальні питання судово-медичної генетики в Україні. Український медичний альманах. 2013. № 1 Т. 16. С. 179-183.

${ }^{4}$ Степанюк Р. Л., Перлін С. І., Кікінчук В. В. Криміналістичне дослідження ДНК: технології та можливості : навч. посіб. Харків, 2019. 144 с.

${ }^{5}$ Там само. С. $7-8$. 
ності такі інформаційні системи : автоматизовані, експертні, консультаційні системи штучного інтелекту, криміналістичні, інформаційно-аналітичні, системи оброблення статистичної інформації, оперативно-розшукові та ін.

Останніми роками сталися суттєві зміни у визначенні предмета криміналістичної тактики, а їі становлення характеризується нерівномірністю розвитку, гіперболізацією окремих іiі частин і напрямів. За генезисом цього питання ми з'ясували, що в різні часи існували різні тенденції: наприклад, до вивчення тактики злочинної діяльності, вивчення особи й типу злочинця, згодом поширення набув напрям слідчої тактики та напрацювання прийомів слідчої діяльності. За дослідженням встановлено, що криміналістичне забезпечення діяльності органів досудового слідства й дізнання складається із напрацювання і впровадження систем тактичних прийомів проведення окремих слідчих (розшукових) дій, їх систем у вигляді тактичних комбінацій, типових тактичних комплексів і тактичних операцій. За визначенням відомого криміналіста В. Ю. Шепітька, сучасний стан криміналістичної теорії дає змогу поставити питання щодо необхідності розроблення і застосування систем тактичних прийомів, які є оптимальним засобом виявлення доказової інформації та іiї використання у судово-слідчій практиці ${ }^{1}$, що ми підтримуємо. Новою проблемою в криміналістиці $€$ використання негласних заходів під час розслідування, які доцільно використати як докази в досудовому розслідуванні та під час дізнання (зокрема, це стосується застосування комплексів слідчих (розшукових) дій, оперативно-розшукових та організаційно-технічних заходів щодо завдань розслідування, тобто тактичних операцій, доцільність чого підтверджено практикою). Так, на підставі емпіричних досліджень І. М. Комаров підрахував, що 75 \% анкетованих ним працівників слідства й дізнання вбачають особливу необхідність у застосуванні криміналістичних операцій у своїй практичній діяльності під час виявлення, розкриття, розслідування та попередження складних видів злочинів ${ }^{2}$. Зі свого боку, згідно з нашим опитуванням працівників поліції, які проходили підвищення кваліфікації, цю тенденцію зазначали 89,9 \% працівників досудового розслідування, 79,9 \% дізнання поліції та 93,7 \% працівників Державного бюро розслідування. Синтезуюче значення та роль у криміналістиці виконує криміналістична методика, яка поєднує рекомендації криміналістичної техніки й тактики та допомагає в досудовому розслідуванні певних видів кримінальних правопорушень. За визначенням І. Ф. Герасимова і Л. Я. Драпкіна, методика розслідування окремих видів кримінальних правопорушень є складовою криміналістики, у якій розглядають методи й засоби, що їх використовують під час виявлення, розкриття та розслідування певних видів і груп

${ }^{1}$ Шепітько В. Ю. Криміналістична тактика (системно-структурний аналіз) : монографія. Харків, 2007. С. 112.

${ }^{2}$ Комаров И. М. Криминалистические операции в досудебном производстве : монография. Барнаул, 2002. С. 33 . 
кримінальних правопорушень на підставі криміналістичної характеристики та типових слідчих ситуацій ${ }^{1}$. Більш поширене визначення криміналістичної методики, сформульоване відомим криміналістом В. А. Журавлем, який зазначив, що криміналістична методика як система знань і самостійний розділ криміналістики має вдосконалюватися через узагальнення та теоретичне пояснення накопиченого емпіричного матеріалу й пізнання наукових фактів, які належать до сфери вчинення, розкриття та попередження кримінальних правопорушень, і що доцільно викладати методичні рекомендації у більш доступній для сприйняття формі (зокрема, у вигляді певних алгоритмічних схем, які можна реалізувати на базі сучасних комп'ютерних технологій) ${ }^{2}$, що ми підтримуємо. У криміналістичній літературі поширювались пропозиції щодо запровадження програмування й алгоритмізації процесу розслідування, створення доцільних програм для слідчого. Щодо цього ще 2007 р. знана криміналістка В. О. Коновалова зазначала, що перспективним є впровадження певних алгоритмічних схем (програм) дій слідчого в певних ситуаціях розслідування ${ }^{3}$, що свідчило про появу перспективного напряму розвитку криміналістики. Це підтверджено сьогоденням: нині науковця чи практика не дивують запропоновані в дисертаціях конкретні алгоритми дій для слідчого, дізнавача і прокурора, а на практиці це теж не $є$ новиною не тільки для слідчого, а й для інших представників правопорядку (наприклад, поліції). Щодо перспектив подальшого розвитку виду та змістовного наповнення криміналістичних методик В. А. Журавель доволі слушно зауважив, що з'ясування цієї проблеми залежить передусім від наявності єдиної загальновизнаної та несуперечливої класифікації методик розслідування злочинів, оскільки до різних класифікаційних рівнів методик можуть бути запропоновані різні технологічні підходи щодо їх утворення (розбудови). Він запропонував таку 4-рівневу структуру криміналістичних методик розслідування: 1) міжвидові (групові) окремі; 2) видові окремі; 3) підвидові окремі; 4) комплексні окремі ${ }^{4}$.

Висновки. Криміналістичне забезпечення діяльності слідчого й дізнавача у протидії злочинності можна класифікувати за такими напрямами: техніко-криміналістичний - за рахунок запровадження і розроблення нових науково-технічних засобів, техніко-криміналістичних прийомів, телекомунікаційних та інших сучасних інформаційних технологій; організаційно-тактичний — за рахунок напрацювання відповідної

${ }^{1}$ Герасимов И. Ф. Общие положения методики расследования преступлений. Криминалистика : учебник ; под ред. И. Ф. Герасимова, Л. Я. Драпкина. Москва, 1994. C. 325.

2 Журавель В. А. Сучасні концепції формування окремих криміналістичних методик розслідування злочинів. Вісник Національної академії правових наук України. 2007. Вип. 2 (49). С. $177-184$.

Коновалова В. О. Алгоритмізація в теорії криміналістики. Там само. Вип. 1 (48). С. 169-174.

${ }^{4}$ Журавель В. А. Зазнач. твір. С. 174. 
тактики досудового розслідування і слідчих дій у разі запровадження новітніх тактичних прийомів і алгоритмів та їх систем, використання при цьому тактичних операцій і оперативних комбінацій; методичний - формування й запровадження окремих криміналістичних методик. Системне криміналістичне забезпечення досудового розслідування, яке проводять слідчий і дізнавач, прокурор, спеціаліст-криміналіст, експерт за напрямами знань, сприяє вдосконаленню виявлення, розкриття й розслідування та дізнавання кримінальних правопорушень, протидії кримінальним правопорушенням відповідно до наукових пропозицій і рекомендацій щодо організації їх службової діяльності. Отже, концептуальні дослідження подальшого вдосконалення криміналістики та іiі місця в правовій науці $є$ нагальними на сучасному етапі розвитку України. Утім, порушені у цій статті питання не є остаточними та потребують додаткового окремого дослідження або наукового вивчення.

\section{References}

Bakhin, V. P. (1987). Sledstvennaia situatsiia i takticheskoe reshenie. Spetsializirovannyi kurs kriminalistiki : uchebnik. Kiev [in Russian].

Belkin, R. C. (1997). Kurs kriminalistiki : v 3-kh t. T. 1 : Obshchaia teoriia kriminalistiki. Moskva [in Russian].

Belkin, R. S. (2000). Kriminalisticheskaia entsiklopediia. 2-e izd., dop. Moskva [in Russian].

Belkin, R. S. (1986). Obshchaia teoriia sovetskoi kriminalistiki. Saratov [in Russian].

Bernaz, V. D., Biriukov, V. V., Volobuiev, A. F. (2011). Kryminalistyka : pidruchnyk ; za zah. red. A. F. Volobuieva. Kharkiv [in Ukrainian].

Gerasimov, I. F. (1994). Obshchie polozheniia metodiki rassledovaniia prestuplenii. Kriminalistika : uchenik ; pod red. I. F. Gerasimova, L. IA. Drapkina. Moskva [in Russian].

Goncharenko, V. I. (1980). Ispolzovanie dannykh estestvennykh i tekhnicheskikh nauk $v$ ugolovnom proizvodstve (Metodologicheskie voprosy) : monograf. Kiev [in Ukrainian].

Danshyn, M. V. (2014). Mistse kryminalistyky u systemi yurydychnykh nauk : avtoref. ... dys. d-ra yuryd. nauk. Kharkiv [in Ukrainian].

Dunaiev, O.V. (2013). Aktualni pytannia sudovo-medychnoi henetyky v Ukraini. Ukrainskyi medychnyi almanakh. № 1 T. 16 [in Ukrainian].

Diachenko, N. M. (2011). Osnovni etapy rozvytku molekuliarno-henetychnoi ekspertyzy v Derzhavnomu naukovo-doslidnomu ekspertno-kryminalistychnomu tsentri MVS Ukrainy. Kryminalistychnyi visnyk. № 1 (15) [in Ukrainian].

Zhuravel, V. A. (2007). Suchasni kontseptsii formuvannia okremykh kryminalistychnykh metodyk rozsliduvannia zlochyniv. Visnyk Nacionalnoi akademii pravovykh nauk Ukrainy. Vyp. 2 (49) [in Ukrainian].

Zhuravel, V. A. (2018). Sytuatsiia slidcha. Velyka ukrainska yurydychna entsyklopediia: u 20 t. T. 20 : Kryminalistyka, sudova ekspertyza, yurydychna psykholohiia ; redkol. V. Yu. Shepitko (holova) ta in. Kharkiv [in Ukrainian].

Shepitko, V. Yu., Zhuravel, V. A., Konovalova, V. O. (2019). Kryminalistyka : pidruchnyk : u 2 t. T. 1 ; za red. V. Yu. Shepitka. Kharkiv [in Ukrainian]. 
Komarov, I. M. (2002). Kriminalisticheskie operatsii v dosudebnom proizvodstve : monograf. Barnaul [in Russian].

Konovalova, V. O. (2007). Alhorytmizatsiia v teorii kryminalistyky. Visnyk Nacionalnoi akademii pravovykh nauk Ukrainy. Vyp. 1 (48) [in Ukrainian].

Kryminalistyka (2004). Pidruchnyk ; za red. V. Yu. Shepitka. 3-tie vyd., pererob. i dopov. Kyiv [in Ukrainian].

Kryminalnyi protsesualnyi kodeks Ukrainy : Zakon Ukrainy vid 13.04.2012 r. № 4651VI (zi zmin. ta dopov.). URL: https://zakon.rada.gov.ua/laws/show/4651-17 (data zvernennia: 18.09.2020) [in Ukrainian].

Maiorov, A. V. (2014). Viktimologicheskaia model protivodeistviia prestupnosti : monograf. Moskva [in Russian].

Matusovskii, G. A. (1976). Kriminalistika v sisteme nauchnykh znanii. Kharkov [in Russian].

Shepitko V. IU. (2003). Tendentsiï i perspektivi rozvitku kriminalistiki (kontseptualnist pidkhodiv i diskusiinist pogliadiv). Aktualni problemi kriminalistiki : mat-li Mizhnar. nauk.-prakt. konf. (Kharkiv, 25-26.09.2003). Kharkiv [in Ukrainian].

Mostovshchikov, E. Professor na trope voiny. Russkii reporter. 10.04.2014. URL: https:// expert.ru/russian_reporter/2014/14/professor-na-trope-vojnyi (data zvernennia: 20.02.2021) [in Ukrainian].

Smakhtin, E. V. (2009). Kriminalistika: sootnoshenie s ugolovnym i ugolovno-protsessualnym pravom : monograf.; pod obshch. red. A. S. Podshibiakina. Moskva [in Russian].

Stepaniuk, R. L., Perlin, S. I., Kikinchuk, V. V. (2019). Kryminalistychne doslidzhennia DNK: tekhnolohii ta mozhlyvosti : navch. posib. Kharkiv [in Ukrainian].

Shepitko, V. Yu., Zhuravel, V. A. (2009). Typovi systemy taktychnykh pryiomiv: problemy rozrobky ta efektyvnoho zastosuvannia. Pytannia borotby zi zlochynnistiu : zb. nauk. pr. Kharkiv, Vyp. 17. 237-251 [in Ukrainian].

\section{A. А. Юхно}

\section{Криминалистическое обеспечение деятельности учреждений судебных экспертиз и органов предварительного расследования и дознания в противодействии преступности}

Рассмотрены проблемные вопросы криминалистического обеспечения деятельности органов досудебного расследования и дознания в противодействии уголовным правонарушениям.

Охарактеризованы понятие и сущность противодействия преступлениям. Проанализированы национальное уголовно-процессуальное законодательство, ведомственная нормативно-правовая база и изменения к ним, касающиеся исследуемого направления, генезис научных позиций по теоретическим и прикладным вопросам криминалистического обеспечения деятельности органов досудебного расследования и дознания в указанном направлении, а также генезис понятия и сути криминалистики как науки. Исследовано современное состояние развития криминалистики, имеюшиеся проблемные вопросы и изелесообразность изменения научной парадигмы криминалистики, применения при этом инноваций; определены пути 
их совершенствования. Теоретические и прикладные проблемные вопросы криминалистики подлежат тщзательному исследованию и решению. Кардинальные изменения необходимы как в целом криминалистике, так и отдельным её направлениям. в реформировании нуждаются действующее законодательство, правоохранительные органы, экспертные учреждения, органы прокуратуры и судебные инстанции, а также правоприменительная деятельность, в которую внедряются современные достижения науки и техники (в частности, компьютерные и телекоммуникационные технологии). Освещены такие проблемные вопросы, как совершенствование криминалистической характеристики отдельных видов преступлений, криминалистической методики, объединяющей криминалистическую технику и тактику. Отдельно и полно рассмотрен вопрос дальнейшего внедрения в правоприменительную и экспертную деятельность перспективных для досудебного расследования молекулярно-генетических экспертиз, в том числе методом ДНК-анализа. По результатам исследования представлены конкретные авторские предложения и рекомендации по изученному направлению деятельности в целом и по отдельным направлениям.

Ключевые слова: криминалистика, генезис, научная позиция, усовершенствование, следователь, дознаватель, прокурор, учреждения судебных экспертиз, судебный эксперт, обеспечение, противодействие преступности, наука, формы, методы, методика, научно-технические средства.

\section{O. Yukhno}

\section{Forensic support of the activities of forensic science institutions and} pre-trial investigation and inquiry bodies in counteraction to crime

Pressing issues of forensic support of activities of pre-trial investigation and inquiry bodies in countering criminal offenses are outlined.

The concept and essence of crime counteraction are considered. The article analyzes the national criminal procedural legislation, departmental regulatory legal framework and their amendments concerning the direction under study, genesis of scientific findings on theoretical and applied issues of forensic support of the activities of pre-trial investigation and inquiry bodies in this direction, as well as the genesis of the concept and essence of forensic science as a science. The modern state of the development of forensic science, current high-priority issues and feasibility of changing the scientific paradigm of forensic science as well as the use of innovations are studied; ways for their improvement are proposed. Theoretical and applied problematic issues of criminalistics are subject to thorough study and resolution. Fundamental changes are required both in criminalistics in general and in particular in its individual areas. The current legislation, law enforcement agencies, forensic science institutions, prosecutors' bodies and judicial bodies, as well as law enforcement, in which modern advances in science and technology (in particular, computer and telecommunication technologies) are being implemented should be reformed. The article highlights 
such problematic issues as the improvement of the forensic characteristics of certain types of crimes, forensic techniques combining forensic techniques and tactics. The issue of further implementation in law enforcement and forensic expert activities of promising molecular genetic examinations for pre-trial investigation bodies, including the method of DNA analysis is outlined separately and fully. Relying on the results of research, specific author proposals and recommendations are provided on the studied area of activity in general and in individual directions.

Keywords: criminalistics, genesis, scientific viewpoint, improvement, investigator, inquiry body, prosecutor, forensic science institutions, support, crime counteraction, science, forms, methods, methodology, scientific and technical tools.

Надійшла до редколегії 26.02.2021 p.

Юхно О. О. Криміналістичне забезпечення діяльності установ судових експертиз та органів досудового розслідування і дізнання у протидії злочинності. Теорія та практика судової експертизи і криміналістики : зб. наук. пр. / редкол.: О. М. Клюєв, В. Ю. Шепітько та ін. Харків : Право, 2021. Вип. 23. С. 61—74. DOI: https://doi.org/10.32353/khrife.1.2021.04. 